\title{
Effect of different
}

\section{Pilates workout endings on the kyphotic and lumbar lordotic angles}

Efeito de diferentes finalizações

do método Pilates sobre

os ângulos de curvatura da

coluna lombar e torácica

Jessica Marques da Silva (iD ${ }^{1}$

Josiele Folletto Bianchin (1) ${ }^{1}$

Emanuelle Francine Detogni Schmit (D) ${ }^{2}$

Cláudia Tarragô Candotti (i) ${ }^{1}$

Adriane Vieira (1) ${ }^{\text {* }}$

${ }^{1}$ Universidade Federal do Rio Grande do Sul (UFRGS), Porto Alegre, RS, Brazil

${ }^{2}$ Centro Universitário Cesuca, Cachoeirinha, RS, Brazil

Date of first submission: June 28, 2018

Last received: June 14, 2021

Accepted: June 22, 2021

Associate editor: Aldo Fontes-Pereira

*Correspondence: adriane.vieira@gmail.com

\begin{abstract}
Introduction: There are no studies that investigate whether different workout endings of the Pilates method $(P M)$, either prioritizing the activation of powerhouse muscles or the relaxation of muscles trained during the session, affects spinal curvature. Objective: Identify the immediate effect of a PM session that ends with soft tissue mobilization or wall exercises on the kyphotic and lumbar lordotic angles. Methods: A crossover clinical trial with 19 female Pilates practitioners that used a Flexicurve ruler to evaluate thoracic and lumbar spine curvature before and after a PM exercise protocol, and after endings that involved soft tissue mobilization using massage balls or wall exercises. The order of the different endings was chosen by random draw and the study volunteers participated in two interventions, with intervals of seven to ten days between them. Two twoway ANOVAs were performed (one for each postural variable), using the factors "assessment time" (presession; post-PE; post-ending) and "type of ending" (soft tissue or wall exercises). Results: There was no significant difference between the assessment times or endings for the kyphotic ( $p=0.972 ; p=0.747)$ and lumbar lordotic angles ( $p=0.574 ; p=0.627$ ), respectively. Conclusion: Pilates instructors can opt for more relaxing or more active endings without affecting the kyphotic and lumbar lordotic angles.
\end{abstract}

Keywords: Exercise therapy. Spinal curvature. Massage. Posture. 


\section{Resumo}

Introdução: Ainda não há pesquisas que demonstrem se diferentes maneiras de finalização da sessão no método Pilates $(M P)$, priorizando a ativação da musculatura do power house ou o relaxamento da musculatura trabalhada durante a sessão têm efeito sobre os ângulos de curvatura da coluna. Objetivo: Identificar qual é o efeito imediato de uma sessão do MP finalizada com mobilização de tecidos moles ou com exercícios na parede sobre os ângulos das curvaturas da coluna torácica e lombar. Métodos: Trata-se de um ensaio clínico cruzado, composto por 19 mulheres praticantes de Pilates, que avaliou as curvaturas torácica e lombar através do flexicurva antes e após um protocolo de exercícios do MP, e depois as finalizações de mobilização de tecidos moles através de bolas de massagem e de exercícios na parede. A escolha da ordem das diferentes finalizações foi realizada por sorteio e as voluntárias da pesquisa participaram das duas intervenções com intervalos entre sete e dez dias. Para análise, foram realizadas duas ANOVAs two-way (uma para cada variável postural) com os fatores "momento avaliativo" (pré-sessão; pós-PE; pós-finalização) e "tipo de finalização" (tecidos moles e parede). Resultados: Não houve diferença significativa entre os momentos avaliativos e entre o tipo de finalização para os ângulos da cifose dorsal ( $p=$ $0,972 ; p=0,747)$ e da lordose lombar $(p=0,574 ; p=0,627)$, respectivamente. Conclusão: Os profissionais podem propor diferentes formas de finalização, optando por uma finalização mais relaxante ou mais ativa, sem que isso interfira no ângulo das curvaturas torácica e lombar da coluna vertebral.

Palavras-chave: Terapia por exercício. Curvaturas da coluna vertebral. Massagem. Postura.

\section{Introduction}

Some mind-body practices are recognized for contributing to restoring or maintaining good posture, correcting muscle imbalance, and improving the strength and flexibility of postural muscles. ${ }^{1-5}$ These include the Pilates method (PM), created by the German Joseph Pilates in the early 20th century and aimed at promoting balance between the body and mind based on six fundamental principles: breathing, concentration, control, centering, precision and flow. ${ }^{6-8}$

One of the most important principles is centering (powerhouse), which involves correctly activating muscles in the lumbopelvic region and axial elongation. These muscles are constantly activated in Pilates exercises, contributing to better spinal alignment, making it easier to execute balanced movements and improving core motor control. ${ }^{9-12}$

Correct spinal alignment is an important factor in musculoskeletal health because postural changes are related to painful and debilitating conditions. ${ }^{13}$ Additionally, given that spinal problems affect individuals during their most productive time of life, resulting in substantial economic costs to society, ${ }^{14}$ investing in Pilates-type exercises may help prevent these conditions.

The classic method, aimed at maintaining the centering stimulus, ends sessions with wall exercises that promote the contraction of powerhouse muscles, favoring sustained axial elongation and correct spinal alignment. ${ }^{15,16}$ By contrast, the contemporary method focuses on muscle relaxation, using tactile stimuli such as massage balls to generate a feeling of well-being and reduce any pain or discomfort caused by the exercises. ${ }^{17-19}$

Since centering is one of the main objectives of Pilates, ${ }^{20}$ there is a question as to whether relaxation activities at the end of the session may alter the immediate effect of axial elongation, reducing the improved alignment achieved during the session. However, no studies were found in the literature that investigated whether different PM endings affect axial elongation. Our hypothesis is that different stimuli at the end of the session are insufficient to change the position of the spine because maintaining spine curvature involves several different elements, such as ligaments, bone structure, and muscle flexibility, and is not associated solely with the immediate stimulus of muscle activation. ${ }^{21,22}$ As such, this study aimed to identify the immediate effect of a PM session that ends with soft tissue mobilization or wall exercises on the kyphotic and lumbar lordotic angles.

\section{Methods}

This was a crossover clinical trial, with data collected between April and June 2016. Consecutive sampling was used, and participants were healthy non-pregnant women aged 25 to 65 years, who had practiced Pilates for at least three months. Considering the method used to assess the primary outcome of the study, exclusion criteria were deformity in Adam's forward bend test 
(indicating scoliosis), a rash on the back and pain intensity of seven or higher on a verbal numeric scale scored from zero to ten. Individuals were invited to participate on social media, where they were given the researchers' contact details.

Sample size was calculated in GPower 3.1.7 software, based on F-tests (ANOVA repeated measures, withinbetween interaction), considering $\alpha<0.05$, power (1- $\beta$ ) of $95 \%, \%$, two groups, three measurements, an effect size of 0.5 (calculated using an estimated $\eta^{2}$ of 0.2 ), and assuming sphericity and a correlation between measures of 0.5 , resulting in a minimum of 14 individuals. In order to offset possible sample losses of around 30\%, 19 women were included in the study. Ethical precepts were followed and the study only began after approval by the institutional Research Ethics Committee (CAAE: 64083617.2.0000.5347). All participants were volunteers and provided written informed consent.

An initial one-on-one session was scheduled with the women who had contacted the researchers, where the following procedures were performed: (1) reading and signing the informed consent form; (2) application of a questionnaire to obtain characterization data (weight, height and BMI) and information on how long the women had been practicing Pilates; and (3) establishing eligibility according to the inclusion and exclusion criteria. The first 19 volunteers who arrived for the one-on-one session were deemed eligible and included in the study. The draw to determine the order of the different endings was also performed at the first meeting.
Two dates were scheduled for each participant to carry out the intervention and collect data, with a 7 to 10 day interval between them. Based on the order of the endings established by the draw, the interventions were denominated Intervention A (IA), ending with soft tissue mobilization, and Intervention $B(I B)$, which ended with wall exercises. Of the 19 participants, 11 were drawn to execute IA first, and eight IB. Those who began with IA were submitted to IB on the second scheduled date, and vice-versa. The participants were asked not to attend any other PM sessions or exercise programs one week before and during the data collection period. Participants were assessed before the Pilates session (pre-session), then performed the exercise protocol (EP) and were evaluated again (post-EP) using the same procedures. The session ended in line with the random draw (IA-soft tissue and IBwall) and participants were then reassessed (post-ending).

In IA, the workout ended with soft tissue mobilization using an Acte Sports massage ball $(7 \mathrm{~cm}$ in diameter) for 10 minutes. The individual was positioned in ventral decubitus on the Cadillac in order to mobilize the soft tissue, alleviate pain and promote relaxation, especially in the muscles around the thoracic and lumbar spine (Figure 1). ${ }^{17,23}$ The IB session ended with 10 minutes of wall exercises (arm circles, roll downs and squats). The individuals performed the exercises standing up with their backs leaning against a wall and their feet in front of them in the Pilates stance, with their head in a neutral position and arms at their sides with palms facing the wall (Figure 2).

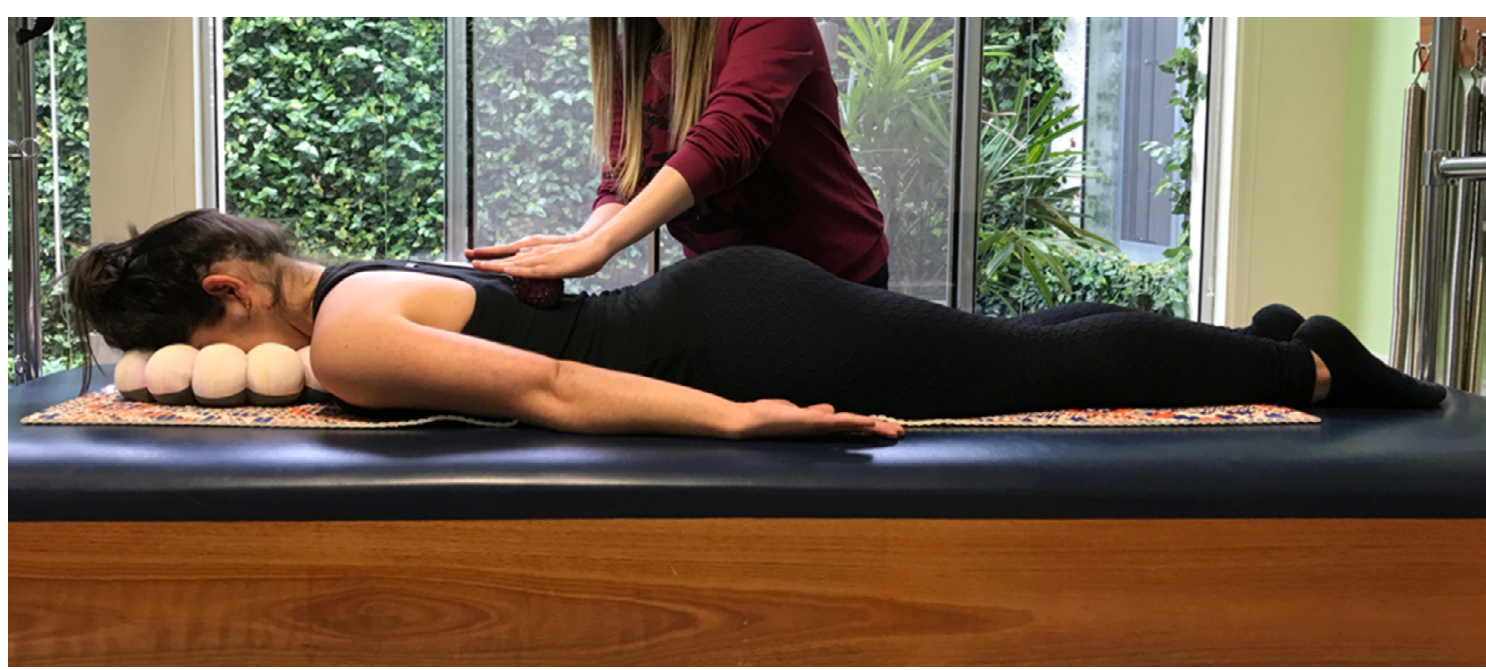

Figure 1 - Soft tissue mobilization using massage balls. 


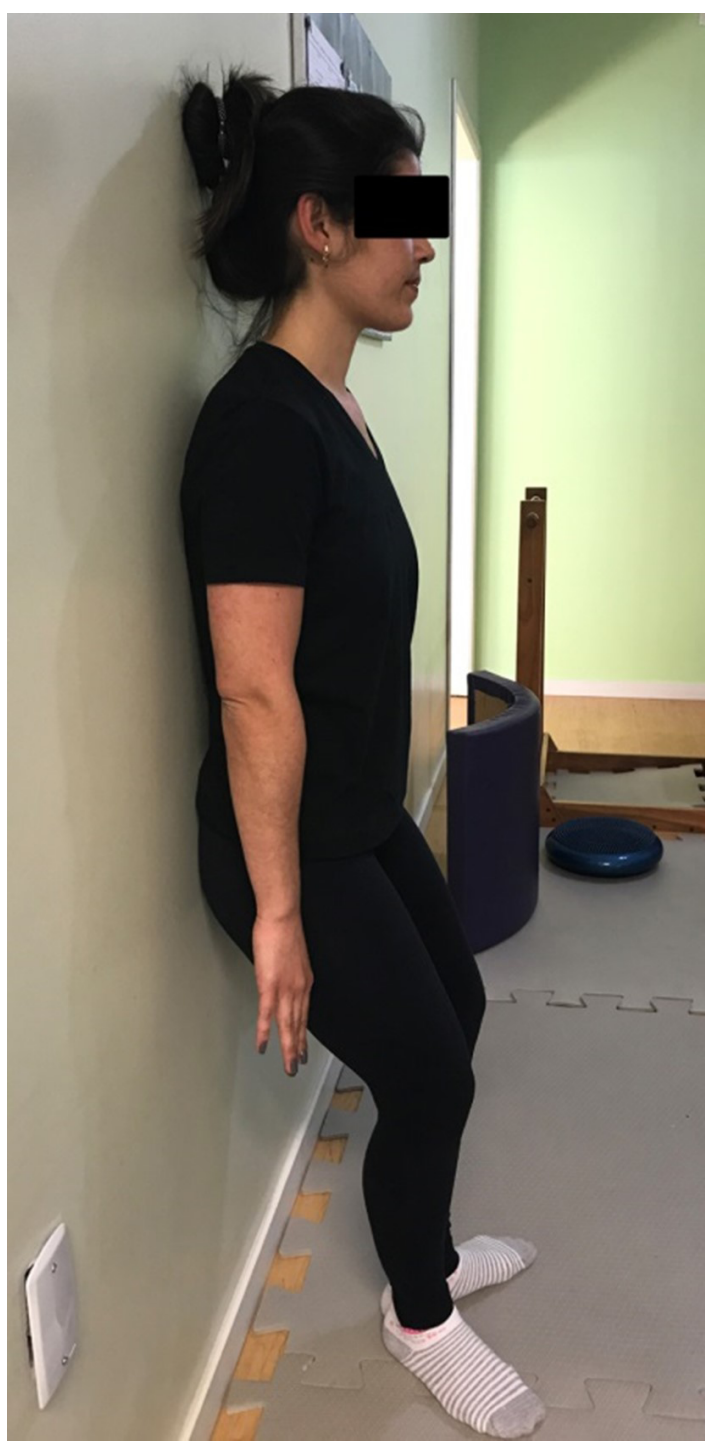

Figure 2 - Initial wall position.

The study outcomes were the kyphotic and lumbar lordotic angles (postural variables) assessed after the endings. A Flexicurve ruler (Trident Indústria de Precisão Ltda, São Paulo, Brazil) was used to measure these outcomes, in order to assess the postural variables (flexicurve and Cobb angles of thoracic and lumbar curvature in the sagittal plane). ${ }^{24,25}$ The Flexicurve is an $80 \mathrm{~cm}$-long strip of flexible metal covered in plastic that can trace curved shapes, allowing it to replicate the curvature of the lumbar and dorsal region when molded against an individual's spine.

For assessment using the Flexicurve, participants were asked to stand facing a wall, with their knees extended and feet parallel, shoulders and elbows flexed at $90^{\circ}$, and their forearms supported against the wall. The spiny processes (SPs) of the C7, T1, T12, L5 and S1 vertebrae were identified by palpation and marked with a wax pencil. The ruler was molded against the back and the locations on the skin markings indicating the SPs were marked on the Flexicure, which was then carefully removed from the back, placed on a sheet of paper, its outline traced and the SPs identified. ${ }^{26}$ The curve drawn on the paper was photographed using a digital camera (Nikon COOLPIX AW130), with the lens placed parallel to the paper. The photograph was imported to BIOMEC-FLEX software and the points (SPS) marked on the drawn curve were digitized. The BIOMECFLEX ${ }^{\odot}$ software provided the angles (Cobb angle) of the postural variables in the sagittal plane (kyphosis and lumbar lordosis). ${ }^{24,25}$

The exercise protocol (EP) was designed especially for this study, based on the researchers' own experience with PM and aimed to include a wide range of exercises that focused on the trunk and the upper and lower limbs (Table 1). The 45-minute workouts were performed on a mat and the Cadillac and Reformer machines (Physio Pilates, Bahia, Brazil) in a set of 10 repetitions each, with the final 10 minutes dedicated to the ending. The sessions were created and performed in line with PM principles (concentration, breathing, centering, control, precision and flow).

Statistical analysis was carried out in SPSS software (v. 20.0), using descriptive and inferential statistics. For the sample characterization data (weight, height, BMI and time involved in PM), multiple one-way ANOVAs were performed (one for each characterization variable), using the factor "age range" (up to 29 years; 30 to 59 years; 60 years and over).

For the primary outcome, two two-way ANOVAs were carried out (one for each postural variable), using the factors "assessment time" (pre-session; postPE; post-ending) and "type of ending" (soft tissue or wall exercises). The Bonferroni post hoc test was used for all the ANOVAs. In line with Field, ${ }^{27}$ For the primary outcome, two two-way ANOVAs were carried out (one for each postural variable), using the factors "assessment time" (pre-session; post-PE; post-ending) and "type of ending" (soft tissue or wall exercises). The Bonferroni post hoc test was used for all the ANOVAs. In line with Field $\left(\eta_{p}{ }^{2}\right)$. Significance was set at $\alpha<0,05$ for all analyses. 
Table 1 - Pilates method exercise protocol (EP)

\begin{tabular}{ll}
\hline Equipment & Exercises \\
\hline Cadillac & Rolling Back: Down/up; Spine Stretch; Front Splits; Side Splits; Mermaid; Swan; Reverse Push Through; Tower: \\
& heel variation, pads of the feet variation, running variation, Achilles stretch variation, pads of the feet in Pilates \\
& V, heel variation in Pilates V position, unilateral pads of the feet variation. \\
Reformer & Arms: Biceps; Arms: Pulling; Arms: Pulling - Variação; Arms: Up and Down. \\
Mat & The Hundred, Roll Up; Single Leg Stretch; Criss cross; Swimming; Leg Pull Front: variation; Spine Stretch \\
& Forward; Saw; Swan. \\
\hline
\end{tabular}

\section{Results}

Participants were 19 women aged between 26 and 65 years, whose anthropometric data are presented in Table 2, stratified by age range. A significant difference between the three age groups $[F(2.73)=27.974 ; p<$ $\left.0.001 ; \eta_{p}^{2}=0.434\right]$ was only observed for time involved in $\mathrm{PM}$, with younger women reporting the shortest time periods and 30 to 59-year-olds the longest.

The primary outcomes were not influenced by the factors analyzed, indicating no difference between the assessment times for the postural variables, regardless of the ending adopted (Table 3). The kyphotic angle showed no significant difference for assessment time $\left[F(2.108)=0.028 ; p=0.972 ; \eta_{p}^{2}=0.001\right]$ or type of ending $\left[F(1.108)=0.105 ; p=0.747 ; \eta_{p}^{2}=0.001\right]$, with no interaction between assessment times and endings. There was no difference in the lumbar lordotic angle for assessment time $\left[F(2.108)=0.557 ; p=0.574 ; \eta_{p}{ }^{2}=\right.$ $0.010]$ or type of ending $[F(1.108)=0.237 ; p=0.627$; $r=0.002]$, and no interaction between assessment times and endings.

Table 2 - Mean and standard deviation of the clinical (weekly frequency and time involved in Pilates) and anthropometric data of the sample, stratified by age group

\begin{tabular}{lcccc}
\hline & Up to $\mathbf{2 9}$ years $(\mathbf{n}=\mathbf{5})$ & $\mathbf{3 0}$ to $\mathbf{5 9}$ years $(\mathbf{n}=\mathbf{7})$ & $\mathbf{6 0}$ years and older $(\mathbf{n}=\mathbf{7})$ & $\mathbf{p}$ \\
\hline Height $(\mathrm{m})$ & $1.6 \pm 0.1$ & $1.6 \pm 0.0$ & $1.6 \pm 0.1$ & 0.983 \\
Weight $(\mathrm{kg})$ & $58.1 \pm 7.2$ & $59.8 \pm 8.3$ & $69.0 \pm 8.2$ & 0.058 \\
BMI (Kg/m2) & $24.4 \pm 4.2$ & $23.9 \pm 2.9$ & $24.1 \pm 2.3$ & 0.975 \\
Time involved in PM (years) & $3.2^{\mathrm{a}} \pm 1.6$ & $5.0^{\mathrm{b}} \pm 0$ & $4.4^{\mathrm{c}} \pm 0.5$ & $<0.001$ \\
\hline
\end{tabular}

Note: PM = Pilates method. Different letters (superscript) indicate a significant difference between age groups.

Table 3 - Mean and standard deviation of the kyphotic and lumbar lordotic angles assessed before the Pilates session and after the ending (tissue mobilization or wall exercises)

\begin{tabular}{|c|c|c|c|c|c|c|}
\hline \multirow[t]{2}{*}{ Variable } & \multicolumn{3}{|c|}{$\begin{array}{c}\text { Intervention A: } \\
\text { soft tissue mobilization }(n=19)\end{array}$} & \multicolumn{3}{|c|}{$\begin{array}{l}\text { Intervention B: } \\
\text { wall }(n=19)\end{array}$} \\
\hline & Pre-session & Post-EP & Post-ending & Pre-session & Post-EP & Post-ending \\
\hline $\begin{array}{l}\text { Dorsal kyphosis } \\
\text { (Cobb angle) }\end{array}$ & $40.0 \pm 11.6$ & $38.9 \pm 10.6$ & $39.2 \pm 11.0$ & $40.4 \pm 11.2$ & $39.5 \pm 10.3$ & $41.2 \pm 11.1$ \\
\hline $\begin{array}{l}\text { Lumbar lordoses } \\
\text { (Cobb angle) }\end{array}$ & $31.5 \pm 9.8$ & $30.8 \pm 8.2$ & $31.2 \pm 9.9$ & $33.9 \pm 10.5$ & $30.0 \pm 7.2$ & $32.2 \pm 10.9$ \\
\hline
\end{tabular}

Note: $E P=$ exercise protocol. 


\section{Discussion}

This study aimed to investigate whether ending a Pilates session with wall exercises, emphasizing the activation of powerhouse muscles to support the body, ${ }^{15}$ or tissue mobilization with massage balls to promote relaxation, ${ }^{28}$ has an immediate effect on kyphotic and lumbar lordotic angles in the sagittal plane. The results demonstrated that there is no significant difference between endings, confirming the hypothesis that soft tissue mobilization at the end of the session does not cause an immediate decline in postural alignment.

A comparison between pre-session and post-EP also showed no significant differences in kyphosis and lumbar lordosis, indicating that the workout was insufficient to alter postural alignment.

Maintaining or altering thoracic and lumbar curvature is linked to the characteristics of different tissues that comprise the spinal column (ligaments, muscle strength, bone structure and muscle flexibility) and motor control, which can only be modified with long-term stimuli. 22,29,30 Studies that assess the long-term effect of PM sessions have identified a noticeable change in thoracic and lumbar spinal alignment in young adults who participate in program s longer than 12 weeks, indicating that this process of remodeling spinal curvature depends on exercise repetition and improved motor control in the long term. ${ }^{31-34}$

Two studies were found in the literature that investigate the immediate effect of an exercise session on thoracic and lumbar spinal alignment. One of the studies assessed the immediate effect of a global postural reeducation (GPR) session ${ }^{25}$ and found no change in thoracic and lumbar spine curvature, and the other evaluated the immediate effect of a PM exercise protocol in adult women with no prior knowledge of or minimal contact with the method. ${ }^{33}$

Krawczky et al. ${ }^{33}$ observed a $1^{\circ}$ reduction in kyphosis when they compared pre- and post-session measurements, and no difference in lumbarcurvature. This result differs from our findings, suggesting that a single PM session may have an immediate noticeable effect on the postural alignment of people who are unfamiliar with the method when compared to regular practitioners. However, further research is needed to confirm this hypothesis, especially because the aforementioned study found only a $1^{\circ}$ difference in kyphosis, making it important to investigate whether this difference is clinically relevant and if the result can be reproduced in other studies comparing beginners with people who have practiced Pilates for more than 15 months. The methodological differences between the present study, which used a Flexicurve ruler, and that conducted by Krawczky et al., ${ }^{33}$ who used photogrammetry, as well as the different exercise protocols, may have contributed to the divergent results.

Although certification courses for different types of Pilates stipulate different workout endings, no studies were found that compare whether endings aimed at activating powerhouse muscles or those targeting relaxation have an immediate or long-term effect on spinal alignment. In the present study, a comparison between endings involving soft tissue mobilization in ventral decubitus and wall exercises performed standing up showed no noticeable immediate effect on kyphotic and lumbar lordotic angles in the sagittal plane. However, additional studies are needed to better understand the effects of these different endings on spinal alignment.

The exercise protocol also had no impact on kyphosis and lumbar lordosis, indicating that a single session in female PM practitioners is insufficient to noticeably alter spinal curvature, since this effect, when present, is related to long-term postural changes. Nevertheless, given that studies have found differences in spinal alignment with regular PM sessions, future studies should investigate whether different endings have different effects on spinal alignment in the long term and if these changes are more related to changes in postural habits, stretching and muscle strength, which may not be linked to how the session ends. The fact that there was no difference between the two endings enables greater freedom in choosing endings for sessions without compromising the result of centering and axial elongation, one of the main objectives of PM. This allows instructors to choose more relaxing or active endings based on their or their clients' preferences.

However, for the purpose of generalization, it is important to consider the limitations of this study. The broad age range of the sample and their different physiological characteristics may have influenced the results, making it important to conduct studies with smaller age ranges, particularly in young women, who have better spinal mobility.34The fact that the researchers were not blind to the interventions and the results being valid only for women are also limitations. As such, the findings obtained here are considered preliminary 
results, since this is the first study to investigate the effect of a single PM session on spinal curvature and further research is needed to reduce bias and overcome the limitations of the present study.

\section{Conclusion}

The results of the present study suggest that neither relaxation through soft tissue mobilization using massage balls nor powerhouse muscle activation via wall exercises has an immediate effect on kyphotic and lumbar lordotic angles in the sagittal plane.

\section{Authors' contributions}

JMS and JFB were responsible for study conception, data collection and writing the manuscript. EFDS and CTC assisted with the methodology and were the second and first reviewers, respectively. AV was responsible for study conception, advising, revision and drafting the final version.

\section{References}

1. González-Gálvez N, Marcos-Pardo PJ, Trejo-Alfaro H, VaqueroCristóbal R. Effect of 9-month Pilates program on sagittal spinal curvatures and hamstring extensibility in adolescents: randomised controlled trial. Sci Rep. 2020;10(1):9977. DOI

2. Campos RR, Dias JM, Pereira LM, Obara K, Barreto MS, Silva $M F$, et al. Effect of the Pilates method on physical conditioning of healthy subjects: a systematic review and meta-analysis. J Sports Med Phys Fitness. 2016;56(7-8):864-73. Full text link

3. Evangelou C, Sakkas GK, Hadjicharalambous M, Aphamis G, Petrou P, Giannaki CD. The effect of a three month, low-loadhigh-repetitions group-based exercise program versus pilates on physical fitness and body composition in inactive women. $J$ Bodyw Mov Ther. 2021;26:18-23. DOI

4. Bullo V, Bergamin M, Gobbo S, Sieverdes JC, Zaccaria M, Neunhaeuserer $D$, et al. The effects of Pilates exercise training on physical fitness and wellbeing in the elderly: a systematic review for future exercise prescription. Prev Med. 2015;75:1-11. DOI
5. Kliziene I, Sipaviciene S, Vilkiene J, Astrauskiene A, Cibulskas G, Klizas S, et al. Effects of a 16-week Pilates exercises training program for isometric trunk extension and flexion strength. J Bodyw Mov Ther. 2017;21(1):124-32. DOI

6. Di Lorenzo CE. Pilates: what is it? Should it be used in rehabilitation? Sports Health. 2011;3(4):352-61. DOI

7. Wells C, Kolt GS, Bialocerkowski A. Defining Pilates exercise: a systematic review. Complement Ther Med. 2012;20(4):25362. DOI

8. Oliveira LC, Pires-Oliveira DAA, Abucarub AC, Oliveira LS, Oliveira RG. Pilates increases isokinetic muscular strength of the elbow flexor and extensor muscles of older women: A randomized controlled clinical trial. J Bodyw Mov Ther. 2017; 21(1): 2-10. DOI

9. Kolyniak Filho C, Garcia IEG. O autêntico método pilates de condicionamento físico e mental (contrologia): contribuições para uma fundamentação teórica. São Paulo: Stampato; 2012.

10. Panhan AC, Gonçalves M, Eltz GD, Villalba MM, Cardozo AC, Bérzin F. Core muscle activation during Pilates exercises on the Wunda chair. J Bodyw Mov Ther. 2021;25:165-9. DOI

11. Key J. 'The core': understanding it, and retraining its dysfunction. J Bodyw Mov Ther. 2013;17(4):541-59. DOI

12. Panhan AC, Gonçalves M, Eltz GD, Villalba MM, Cardozo AC, Bérzin F. Electromyographic evaluation of trunk core muscles during Pilates exercise on different supporting bases. J Bodyw Mov Ther. 2019;23(4):855-9. DOI

13. Rosa BN, Furlanetto TS, Noll M, Sedrez JA, Schmit EFD Candotti CT. 4-year longitudinal study of the assessment of body posture, back pain, postural and life habits of schoolchildren. Motricidade. 2017;13(4):3-12. DOI

14. Rodrigues TCC, Costa JSD. Internações por dorsopatias na população adulta no estado do Rio Grande do Sul de 2008 a 2016. J Health Biol Sci. 2019;7(1):41-6. DOI

15. Picolli F. Efeitos do treinamento proporcionado pelo método Pilates clássico nas aptidões físicas em mulheres saudáveis: um ensaio clínico controlado [master's thesis]. Porto Alegre: Universidade Federal do Rio Grande do Sul; 2010. Full text link 
16. Siqueira GR, Alencar GG, Oliveira ECM, Teixeira VOM. Efeito do pilates sobre a flexibilidade do tronco e as medidas ultrassonográficas dos músculos abdominais. Rev Bras Med Esporte. 2015;21(2):139-43. DOI

17. Florentino DM, Sousa FRA, Maiworm Al, Carvalho ACA, Silva KM. A fisioterapia no alívio da dor: uma visão reabilitadora em cuidados paliativos. Rev Hosp Univ Pedro Ernesto. 2012;11(2):50-7. Full text link

18. Alves M Jardim M, Gomes B, Freitas O. Efeitos da massagem terapêutica na saúde mental das pessoas com patologia oncológica. Rev Port Enferm Saude Mental. 2015;(Ed Es 2):11922. Full text link

19. McNeill W. Pilates: Release or recruit? J Bodyw Mov Ther. 2012;16(1):101-4. DOI

20. Muscolino JE, Cipriani S. Pilates and the "powerhouse"-I. J Bodyw Mov Ther. 2004;8(1):15-24. DOI

21. Rossi LP, Brandalize M, Gomes ARS. Efeito agudo da técnica de reeducação postural global na postura de mulheres com encurtamento da cadeia muscular anterior. Fisioter Mov. 2011;24(2)255-63. DOI

22. Tsao $H$, Hodges PW. Immediate changes in feedforward postural adjustments following voluntary motor training. Exp Brain Res. 2007;181(4):537-46. DOI

23. Abreu MF, Souza TF, Fagundes DF. Os efeitos da massoterapia sobre o estresse físico e psicológico. Rev Cient Fac Educ e Meio Ambien. 2012;3(1):101-5. DOI

24. Candotti CT, Kostopoulos N, Dutra VH, Raupp EG, Loss JF. Manual de utilização do BIOMECFLEX v.3.0: Software para avaliação da coluna vertebral. Porto Alegre: UFRGS; 2016. Full text link

25. Barrett E, McCreesh K, Lewis J. Intrarater and interrater reliability of the flexicurve index, flexicurve angle, and manual inclinometer for the measurement of thoracic kyphosis. Rehabil Res Pract. 2013;2013:475870. DOI
26. Oliveira TS, Candotti CT, La Torre M, Pelinson PPT, Furlanetto TS, Kutchak FM, et al. Validity and reproducibility of the measurements obtained using the flexicurve instrument to evaluate the angles of thoracic and lumbar curvatures of the spine in the sagittal plane. Rehab Resear and Pract. 2012:186156. DOI

27. Field A. Descobrindo a estatística usando o SPSS-5. Porto Alegre: Penso Editora; 2009.

28. Loghmani MT, Whitted M. Soft tissue manipulation: a powerful form of mechanotherapy. Physiother Rehabil. 2016;1(4):1000122. DOI

29. Richardson C, Hodges PW, Hides J. Fisioterapia para estabilização lombopélvica. um sistema de controle motor para tratamento e prevenção da lombalgia. São Paulo: Phorte Editora; 2012.

30. Tsao H, Hodges PW. Persistence of improvements in postural strategies following motor control training in people with recurrent low back pain. J Electromyogr Kinesiol. 2008; 18(4):559-67. DOI

31. Cruz-Ferreira A, Fernandes J, Kuo $Y L$, Bernardo $L M$, Fernandes $O$, Laranjo $L$, et al. Does Pilates-based exercise improve postural alignment in adult women? Women Health. 2013;53(6):597-611. DOI

32. Junges S, Gottlieb MG, Baptista RR, Quadros CB, Resende TL, Gomes I. Eficácia do método Pilates para a postura e flexibilidade em mulheres com hipercifose. R Bras Ci e Mov. 2012;20(1):21-33. Full text link

33. Krawczky B, Mainenti MRM, Pacheco AGF. The impact of Pilates exercises on the postural alignment of healthy adults. Rev Bras Med Esporte. 2016;22(6):485-90. DOI

34. Lee ES, Ko CW, Suh SW, Kumar S, Kang IK, Yang JH. The effect of age on sagittal plane profile of the lumbar spine according to standing, supine, and various sitting positions. J Orthop Surg Res. 2014:9:11. DOI 